\title{
THE CROWN'S RELATIONSHIP WITH TRIBAL PEOPLES AND THE LEGAL DYNAMICS FOR THE RESOLUTION OF HISTORICAL AND CONTEMPORARY CLAIMS
}

\author{
PG McHugh*
}

\begin{abstract}
This article reflects upon themes and foundations of the contemporary legalism attending the resolution of aboriginal claims. It opens with a broad description of the historical foundation of that legalism in the imperial prerogative of the Crown and its continuance in the national constitutional systems of Canada and New Zealand. It then considers how that legalism, with its origination in the imperial prerogative and the ongoing comparative dimension associated with that origin, inhabits a recent local example, namely New Zealand's Marine and Coastal Area (Takutai Moana) Act 2011. The article shows how this provision reflects the general features of indigenous rights' jurisprudence as it has emerged over the past 30 years: it carries residual elements of the imperial prerogative and it has a comparative element, yet it is also a peculiarly New Zealand instance that marks a new step in the jurisprudence.
\end{abstract}

\section{INTRODUCTION}

The law surrounding the resolution of indigenous peoples' claims against the state (as personified in the Crown) has been an area of considerable growth in the common law jurisdictions of Canada, Australia and New Zealand over the past three decades. Much of the indigenous rights scholarship encouraging and accompanying this growth has been in a comparative vein, the nature of which has influenced national courts and legislatures significantly. Of course this scholarship and the jurisprudence to which it has contributed have acquired a homegrown quality. In Canada this national flavour has been the effect of the constitutional recognition of "existing aboriginal and treaty rights" in s 35 of the Constitution Act, $1982,{ }^{1}$ whilst the New Zealand legalism has been

\footnotetext{
* Professor of Law and Legal History, University of Cambridge.

1 Constitution Act, 1982, sch B to the Canada Act 1982 (UK) c 11.
} 
shaped by a statutory pattern of recognising the "principles of the Treaty of Waitangi" as well as the impact of "mixed member proportional" (MMP) electoral politics in pressing the pace of settlement and determining legislative design. Nonetheless, the comparative dimension of the legal regimes for the resolution of aboriginal claims has always been an important feature in this rapid growth of the past 30 years. This is growth to which I have been a witness and occasional, privileged participant. "Indigenous peoples" rights describes an area in which scholars associated with Victoria University of Wellington (VUW) have made a significant contribution, as well as numerous judges and political figures. Looking at the complete index to the Victoria University of Wellington Law Review (VUWLR), one sees the rise of this field from the early-1980s, not only through the publications of established academics but also in numerous articles by young scholars in the Faculty's Honours and Masters programmes. Most of us linked to the Faculty have, in one way or another, benefited from its encouragement to scholarly enterprise, embodied by Professor Bill Atkin and his commitment to academic excellence in the Honours programme and academic publishing through the VUWLR. Of course Bill has not kept these so healthily afloat alone, though he has been a very major mainstay of these gleaming aspects of Faculty activity over the past 30 years. Likewise there are scholars from other New Zealand faculties who have made considerable contribution to the scholarship, though the VUW contribution seems to me as a whole, far to outshine other Faculties. For myself, I have published more of my major articles in VUW legal periodicals than elsewhere. In large part this reflects the institutional loyalty and abiding affection that Bill has been so instrumental in fostering. It is an honour to offer this article to Bill (and Virginia) as a token of esteem, gratitude and immense fondness.

This article is a reflection upon themes and foundations of the contemporary legalism attending the resolution of aboriginal claims. In keeping with a form of scholarship that has been at once both comparative and home-grown, I do this by opening with a broad description of the historical foundation of that legalism in the imperial prerogative of the Crown and its continuance in the national constitutional systems of Canada and New Zealand. I then consider how that legalism, with its origination in the imperial prerogative and the ongoing comparative dimension associated with that origin, inhabits a recent local example. This example will be the customary marine title (CMT) provisions of Te Takutai Moana Act 2011. Section 58 of this Act sets out the statutory test for CMT, the fullest entitlement that Māori can establish by law over foreshore and seabed lands. I will show how this provision reflects the general features of indigenous rights' jurisprudence as it has emerged over the past 30 years: it carries residual elements of the imperial prerogative and it has a comparative element, yet it is also a peculiarly New Zealand instance that marks a new step in the jurisprudence.

Māori rights over the foreshore and seabed became a topic of national controversy following the Court of Appeal's judgments in the Ngati Apa case (2003). ${ }^{2}$ Addressing and containing the

2 Attorney-General v Ngati Apa [2003] 3 NZLR 643 (CA). 
possibility of Māori rights over the New Zealand coastline was probably the stickiest and most emotive issue during the premiership of Prime Minister Helen Clark, and the fifth Labour Government (1999-2008). The Labour Party-Rātana alliance forged during the inter-war years collapsed under the strain and a new political party was formed. This new Māori Party has participated in coalition government and been instrumental in redrawing the terms of Māori political participation and their newfound status as king-making parliamentary players. This influence could probably have not been possible under the old "first past the post" electoral system, but the politics of MMP, the system introduced in 1996 after a series of referenda, altered that system's allowance of majoritarian dominance for a more fluid, interest-based form in which Māori have consistently displayed great skill. The foreshore and seabed controversy has shown their mastery of the new politics. Where Māori claims against the Crown are concerned, there is no more graphic illustration of this in the second decade of the twenty-first century than the absence of judicial intervention, compared to the jammed dockets of Canadian courts. Incessant recourse to the courts is an expression of frustration and political impotence, and that certainly is not a description applicable to Māori in contemporary New Zealand.

Whilst Māori had consistently claimed rights over the foreshore and seabed since the late-19th century and had gone to court on numerous occasions in unsuccessful efforts to vindicate them, the makings of the legal argument that Ngati Apa dangled without fully addressing (other than in passing and suggestively) went back to an article published in the VUWLR in 1984. ${ }^{3}$ Bill Atkin received the typescript of this article, which was too lengthy in its original form and which, Solomon-like, was split in two. ${ }^{4}$ With his active support, the second half appeared in the VUWLR. Its argument was that Māori held unextinguished property rights around the New Zealand coastline that were recognised by the common law, the article focusing on what was then vexed question of customary sea fisheries. The article reflected the cross-jurisdictional nature of the indigenous rights jurisprudence that was beginning to form in the early 1980s, though at the time this juridical activity was occurring primarily in academic fora (not least Professor Brian Slattery's legendary D Phil dissertation). ${ }^{5}$ It also identified a distinctively New Zealand application (Māori mana over the coastline). In keeping with a form of national jurisprudence that has been simultaneously comparative yet peculiar to its jurisdictional setting, in this article I use (mostly) Canadian material, not only by way of comparison, but also to show its substantive influence on the design of New Zealand law. Elements of the imperial prerogative remain strongly evident and, in my view,

$3 \quad$ PG McHugh "The Legal Status of Maori Fishing Rights in Tidal Water" (1984) 14 VUWLR 247.

4 The first half of the original long article was published as PG McHugh "Aboriginal Title in New Zealand Courts" (1984) 2 Canta LR 235.

5 Brian Slattery "The Land Rights of Indigenous Canadian Peoples" (D Phil Dissertation, Oxford University, 1979). 
necessarily present in this modern legalism. It is also an opportunity to update my ongoing analysis of Māori rights over the foreshore and seabed begun in this journal 30 years ago.

The law attending the Crown's relations with indigenous tribal peoples and the resolution of their claims has its foundation in the royal prerogative in its imperial setting. In Canada and New Zealand, the resolution of historical and contemporary claims usually (if not invariably) entails an undertaking by the Crown to transfer assets held by it as sovereign out of the public weal, with a concomitant undertaking to introduce legislation to authorise the transfer, legally recognise and constitute the governance body and arrangements to hold and manage those assets, and authorise any attendant appropriations. The Crown will hold these national assets as sovereign under the prerogative or by statutory vesting. In making such settlements regarding the disposition of such assets, the Crown is exercising more than a mere contractual capacity. The Crown is agreeing to the exercise of a constitutional capacity derived from the prerogative, an at tribute that other contractual parties lack. Where claims settlements are involved, these pertain to the Crown's holding of title to assets as sovereign and its constitutional capacity as sovereign to introduce legislation, including its ministers' constitutional privilege with regard to financial measures, and its capacity to solicit through Parliament the legal transformation of the arrangement. In Canada and New Zealand, claims settlement is not a mere contract but an undertaking relating to the disposal and transference of sovereign assets through the exercise of sovereign authority. In both countries the settlement of claims is ultimately a political decision taken by the Crown (on the advice of Her responsible Ministers) to exercise constitutional authority over national assets and in the sponsorship of legislation. Further, and as I outline below, this contemporary manifestation of the prerogative is rooted in, and a continuance of, the historical nature of the Crown's relations with indigenous peoples.

We are not speaking of an unadorned prerogative, for the prerogative is, of course, an historical cluster of powers recognised by the common law and in a state of ongoing iteration by and through the common law. ${ }^{6}$ It is basic to the history of the prerogative that it is subject to Parliament (1688 and all that). This subjection to Parliament entails more than the amenability to being overridden by legislation. It includes the responsibility of the Crown's Ministers to Parliament and their constitutional obligation to render an account of their deployment of prerogative authority (given technically as it is by way of "advice"). This form of executive subjection was not an instant one but has a history of ministerial reluctance and parliamentary bridling and (the verb often used) taming, especially as we enter a democratic age towards the end of the 19th century. It is also basic to that iterative history that since the late-20th century advent of judicial review, that certain of the Crown's

6 Compare Kent McNeil "Indigenous Rights Litigation, Legal History and the Role of Experts" (2014) 77 Sask L Rev 173 at $\mathrm{n} 35$ and accompanying text. McNeil sees the prerogative as a stable body of common law doctrine and rules in the history of which the Bill of Rights 1688 seems to be the only event. 
prerogative powers - though not all - may be subject to court scrutiny. The prerogative is a jurisprudential formation that has historicity both generally and with regard to particular powers derived from it. This means that features of contemporary legalism will attend its exercise, but ultimately, and as I will explain, the solicitation of legislation remains a political decision of the Crown. This includes legislation to give effect to the settlement of claims by indigenous peoples.

As will become clear, the pattern of Crown relations with indigenous peoples in New Zealand and Canada carries strong parallels as well as some divergences, the latter tending to emphasise rather than undercut those running similarities. Both countries have a history of political relations with their tribal peoples of a sort have only just commenced in Australia. Since the mid-19th century these political relations have been textually based - in the form of treaties and land cessions that replaced the earlier military and alliance forms. In New Zealand and Canada, the passage of legislation to give effect to land claims settlements is a continuance of this history of the Crown's political relations with indigenous polities. This is a history of agreement making, contestation over the meaning of those agreements and, from the early-1980s, eventual court intervention in the factors pressing for new forms of agreement making (common law aboriginal title, most especially). In this light, the nature of Māori political participation within a system of MMP becomes less a new phenomenon than the continuance, in a modern setting, of an established mode of engagement with the Crown. One might characterise likewise the consensual provisions of Te Takutai Moana Act 2011.

The conduct of Crown-tribe relations has for a long while occurred within what the new Dean of the VUW Law School, Dr Mark Hickford, terms the "political constitution". That is to say, these relations have absorbed the attention of the executive branch and, in different ways at different times, have called for the exercise of sovereign authority that, of course, ultimately derives from the prerogative. Until recent decades, the exercise of those powers has been inside a non-adjudicative constitutional framework. As Hickford's important book Lords of the Land (2011) has shown, the concentration of relations within a sphere wherein the Crown is being called upon to deploy legal powers that its courts will not make the subject of adjudication, does not mean the absence of law. ${ }^{7}$ For centuries, and certainly from the rise of the so-called "Second British Empire" and the appointment of the first permanent Under-Secretary of the Colonial Office (1825), colonial affairs were put on a distinctly administered footing that was amenable to constitutional processes of Parliamentary responsibility, scrutiny and appropriations. Hickford's book also shows how the nature of Crown-tribe relations changed inside a constitutional frame that itself was changing in the momentum of white settlement and, eventually by war, the white newcomers' domination of the country. This article attempts to give the longer history of that frame and how the role of law has changed as the nature of New Zealand and Canadian constitutionalism itself has changed and moved

7 Mark Hickford Lords of the Land: Indigenous Property Rights and the Jurisprudence of Empire (Oxford University Press, Oxford, 2011). 
into an era that has seen the rise of legal constitutionalism. This describes a recent, as well as rising, phase of New Zealand and, more especially since 1982 Canadian, constitutional life in which the courts have gradually taken an active adjudicative role. Individuals and (exceptionally in New Zealand and Canada) the collectivity that the common law has called "aboriginal" are recognised as holding rights that shape the exercise of (aspects of) executive discretion and authority. In Canada those rights also affect the exercise of legislative authority. As Hickford has stressed, the dominance of "political constitutionalism" during the mid-19th century did not entail a legal vacuum. In this era, the absence of judges and adjudication did not mean an absence of law and a constitutionally unordered milieu wherein public authority was running amok. As Hickford stresses with reference to the historical span of his book - the mid-19th century - the exercise of public authority was shaped and contested within a dynamic constitutional frame where the key defining features of modern notions of legal constitutionalism had yet to appear. The constitutional world of today's administrative law and court-monitored rights-based claims against the state lay a good century away from the world of the Aborigines Protection Society. This influential body enjoined Crown "protection" of tribal peoples; that is, the beneficent exercise of executive authority. It was not the "Aboriginal Rights Society".

Generally speaking, and so much as one can make such broad categorisation (as well as taking a more New Zealand than Canadian slant), indigenous claims are either historical or contemporary in nature. Historical claims concern an alleged historical infraction by way of past Crown mistreatment of aboriginal or treaty rights, whereas contemporary claims concern the protection and enhancement of present-day rights, most notably those associated with tribal self-government and extant territorial/land occupation. Historical claims thus call for redress of past wrongs, the effect of which has been lasting and negative, whilst contemporary claims call for the legal instantiation of rights that remain in the present-day exercise by the indigenous polity.

The historical and, for the most part, enduring foundation of Crown-tribe relations in the prerogative has been overlaid (though never wholly replaced) by the trappings of contemporary legalism in the form of statute and common law rights, as well as constitutional convention. This overlay, with its interplay between prerogative on the one hand, and statute and common law rights on the other, reflects the topicality of aboriginal issues, as well as absorbing and reflecting contemporary public law values. Constitutional lawyers are accustomed to this interplay, but it is one that has been less acknowledged in the sphere of Crown-tribe relations in Canada and New Zealand. The prerogative is the ongoing common law manifestation of the sovereignty of the Crown. This sovereignty being in a state of constant iteration, the law governing Crown-tribe relations has always reflected the legalism of its time. This is hardly surprising. Necessarily this law has been shaped by the iterative forces surrounding it, be it through the haphazard course of development through litigation and judicial decision-making, through legislative design, through evolution in legal culture's perception and framing of the nature and province of public law, and the municipal reach of international law. 


\section{THE HISTORICAL FOUNDATION OF CROWN AUTHORITY IN THE PREROGATIVE}

At the beginning of the 17th century the conduct of relations with the indigenous tribes of the New World was associated with the authority of royal charters enabling the settlement of the North Atlantic seaboard. To the extent that these charters contemplated dealings with the tribes, it was as an expression of the foreign relations and military power conferred by these instruments and issued under the royal prerogative. These instruments did not claim an inherent authority over the tribal nations but erected systems of internal government for the wayfaring community (under the prerogative of incorporation and royal allowance of bye-laws). As white settlement of the North Atlantic prospered after the Restoration, relations with the independent tribes (of the interior and within the chartered colonies) were conducted by a series of improvisational agreement-making in a running format that historians have termed the Covenant Chain. ${ }^{8}$ This was a style of relation that had yet to reach a 19th century territorialisation of sovereignty but which also particularly reflected the military importance of the independent tribes of the Ohio Basin during the imperial contest for the American continent that waged through late-18th century. When the military dimension of those relations began to ebb after 1812, and as the Concert of Europe moved towards more territorialising and modernist conceptualisation of the authority of the nation state, the basis of Crown authority over tribal people took a more domestic turn. This turn was particularly pronounced during the 1830s and 1840s, influenced by the aftermath of abolition, the rise of philanthropic concern for aborigines and the evangelical spread of His Word, as well as (from the mid-1840s) massive emigration from the United Kingdom to the white settlement colonies, much of it spurred by domestic agrarian crisis. The turn towards Crown protection as the governing principle had key formative moments during the late-1830s of which might be mentioned the controversy surrounding Lieutenant Governor Bond Head's "removal" policy in Upper Canada, the hearings and Report of the Select Committee on Aborigines (1836-1838), which concentrated mostly on southern Africa, and the annexation of New Zealand accompanied by the Treaty of Waitangi (1840) - the cession of sovereignty by the Māori chiefs.

With this turn during the second quarter of the 19th century, the authorisation of Crown authority issued from the key predicate of its undisputed sovereignty over tribal peoples, its consequence being their status as Crown subjects with full amenability to English law. ${ }^{9}$ The Crown

8 Francis Jennings The Ambiguous Iroquois Empire: The Covenant Chain Confederation of Indian Tribes with English Colonies from Its Beginnings to the Lancaster Treaty of 1744 (WW Norton \& Company, New York, 1984); and Daniel Richter and James H Merrell (eds) Beyond the Covenant Chain: The Iroquois and Their Neighbors in Indian North America: 1600-1800 (Penn State University Press, Philadelphia, 1987).

9 Mark D Walters "The Extension of Colonial Criminal Jurisdiction over the Aboriginal Peoples of Upper Canada: Reconsidering the Shawanakiskie Case (1822-26)" (1996) 46 UTLJ 273; Damen Ward "Constructing British Authority in Australasia: Charles Cooper and the Legal Status of Aborigines in the South Australian Supreme Court, c.1840-60" (2006) 34 Journal of Imperial and Commonwealth History 
accepted and avowed an interim obligation to protect the collective interests of its tribal subjects until such time as they had advanced sufficiently in civilization to become individualised and enfranchised property owners. Protection called for the Crown's beneficent deployment of its prerogative in areas such as the patenting of land titles. It was acknowledged in official practice that the exercise of this dimension of the prerogative, enabling the Crown to make its ungranted land available for white settlement, would be preceded by appropriate arrangements with tribal occupants. Both these processes - the protection of tribal occupancy and the determination of the areas of land available for release and grant to settlers - were a manifestation of the same prerogative, although they were distinctly separate exercises. They were an emanation from the Crown's declared status as feudal overlord and sovereign holding dominium of unpatented lands in the settlement colonies. Whilst colonies obtained legislative authority over the disposal of Crown lands and the revenue therefrom (in return for a local civil list), the prior and entirely separate process - the making of such land available - remained an imperial matter for a good while. The province of Canada obtained that full legislative authority in native affairs and land, and its Ministers the associated prerogative in 1860; New Zealand in 1862. In Canada, the Indian Act $1876^{10}$ was passed under this newly obtained authority; the Numbered Treaties obtained under the prerogative. Other prerogative capacities that affected Crown relations with tribal peoples arose from the sympathetic administration of the criminal law, its constitutional role in the administration of civil justice as parens patriae to a vulnerable class of its subjects, and its commissioning and running of the local civil service. Through this also ran the prerogative to keep the peace and ensure civil order. In New Zealand, the Māori Wars of the 1850s and early-1860s were conducted by the Crown under the peace prerogative, whilst the consequence of civil war - the processes for confiscation of Māori land (which soon became highly messy) ${ }^{11}$ - were by statute passed under this newly obtained legislative authority, the New Zealand Settlements Act 1863.

During the Crown colony period and into the early years of responsible government in the white settlement colonies before transmission of legislative and full executive authority, protection was overseen from London. It was channelled through the Crown's representative, the governor who, in turn, with his commissioned officials undertook this task. This duty of protection was never vested explicitly in the governor under the prerogative (despite a recommendation to that effect from the

483; and Lisa Ford and Brent Salter "From Pluralism to Territorial Sovereignty: The 1816 Trial of Mowwatty in the Superior Court of New South Wales" (2008) 7 Indigenous LJ 67.

10 Indian Act SC $1876 \mathrm{c} 18$.

11 Richard Boast "An Expensive Mistake: Law Courts and Confiscation on the New Zealand Colonial Frontier" in Richard Boast and Richard Hill (eds) Raupatu: The Confiscation of Māori Land (Victoria University Press, Wellington, 2009) 145. 
Select Committee on Aborigines (1837)). ${ }^{12}$ It was an implicit amalgam of the delegating of the various and relevant prerogative powers contained in his instruments of office and the introduction of feudal tenure for settler land titles. Colonial Office practice constantly emphasised the judgment of its man-on-the-spot in maintaining Crown protection. With the arrival of responsible government, colonial ministers had access to the executive levers of this Crown protection, though their legislatures initially lacked a matching legislative capacity. The notion of Crown protection as an executive (and political) trust was engrained in the political branches' demarcation of their spheres: when colonial legislatures commenced to exercise their new capacity it was to augment the programme of civilisation. The protection of tribal peoples' collective interests was treated still as falling within the executive sphere.

As with the prerogative at large, these dimensions of the prerogative particularly affecting the Crown's management of relations with tribal peoples were amenable to replacement by statute. One specific example from the imperial era of protection, so rare as to be almost unique, was the imperial legislation authorising colonial assemblies to pass laws for the swearing of oaths and taking of evidence from non-Christians. ${ }^{13}$ The prerogative powers with regard to the patenting of Crown land were passed over jurisdictionally to colonial assemblies but the imperial authorities retained the capacity to decide what land would be released and made available for, and subject to, those local laws. The settler population's hunger for land was unquenchable in Canada and New Zealand during the 19th century and this was a power in the exercise of which governors were under immense pressure. A noisy colonial press aggravated this by pointing impatiently to unused land occupied by tribal peoples whose interests the Crown was avowing its duty to protect. The colonial legislative authority to dispose of Crown lands was not treated as encompassing the conduct of relations with tribal peoples occupying Crown land. Even after that authority was transmitted (1860 for Canada and 1862 for New Zealand), colonial practice continued the imperial conceptualisation of this as an executive matter. In short, those aspects of the Crown prerogative which enabled its protection of tribal peoples' collective interests were carefully held as the imperially retained and controlled aspect of the prerogative. When responsible government was obtained this remained the preserve of the executive branch, encompassing what were seen and treated as matters of government discretion anterior to activation of the legalism of colonial Crown land legislation.

Imperial officers in London and the colonies with tribal populations as well as the local courts understood Crown protection was a dimension of its sovereign prerogative as an executive matter in

12 "Recommendation I - Protection of Natives to devolve on the Executive" in Report from the Select Committee on Aborigines (British settlements); with the minutes of evidence, appendix and index (House of Commons, Cmnd 425, 1837) at 77 .

13 Colonial Evidence Act 6 Vic c 22 (1843) (Imp) allowing local legislatures to pass laws allowing indigenous peoples to give unsworn evidence. See Shaunnagh Dorsett "Destitute of the knowledge of God: Māori Testimony Before the New Zealand Courts in the Early Crown Colony Period" in Diane Kirby (ed) Past Laws, Present Histories (ANU Press, Canberra, 2012) 39. 
respect of which colonial courts had no jurisdiction as much as the colonial legislatures lacked authority. This was a commonplace of colonial life in Canada and New Zealand. Thus the New Zealand Supreme Court (1877) characterised Crown-tribe relations as constituting "an extraordinary branch of the prerogative, wherein the sovereign represents the whole body-politic, and not, as in the case of ordinary prerogative, merely the supreme executive power". ${ }^{14}$ The Court was clear that: ${ }^{15}$

... the supreme executive government must acquit itself, as best it may, of its obligation to respect native proprietary rights, and of necessity must be the sole arbiter of its own justice.

This remained the standard legal starting point. In 1950 the Supreme Court of Canada reiterated the long-standing and "accepted view that these aborigines are, in effect, wards of the State, whose care and welfare are a political trust of the highest obligation". ${ }^{16}$ Recently, the New Zealand Supreme Court referred to the "political trust" era, when this non-justiciable characterisation was the governing common law approach to Crown-tribe relations. ${ }^{17}$

Though Crown-tribe relations were for a very long while - that is to say from at least the $1830 \mathrm{~s}$ onwards - regarded as under the non-justiciable mantle of Crown protection through its prerogative, it was also accepted that tribal rights might be hardened by statute. In Nireaha Tamaki v Baker (1901) the Privy Council indicated that a sequence of local statutes had dealt with Māori customary title and that any encompassment of traditional occupation rights (in present-day parlance, the aboriginal title) by prerogative alone, if it still existed, had been replaced by the clear words of statute. ${ }^{18}$ These presupposed the existence of a type of customary tenure that could be known to lawyers and discoverable by evidence. The Board indicated that the customary rights of occupation were now on a statutory foundation. It had no truck with the position taken by local courts that a statute could not call what was non-existent into being, although legislation later undid the implications of this by statutorily restoring the principle of the non-cognisability at law of traditional occupation rights. ${ }^{19}$ In a more general sense the Board's position no more than reflected the unremarkable principle shown in De Keyser's Hotel that Crown authority under the prerogative could be replaced by statute. ${ }^{20}$

14 Wi Parata v Bishop of Wellington (1877) 3 NZ Jur (NS) 72 at 79.

15 At 78 .

16 St Ann's Island Shooting and Fishing Clubv The King [1950] SCR 211.

17 Paki v Attorney-General [2014] NZSC 118, [2015] 1 NZLR 67 at [42] n 76, and at [160] per Elias CJ.

18 Nireaha Tamaki v Baker [1901] AC 561 (PC). For discussion JW Tate "Hohepa Wi Neera: Native Title and the Privy Council Challenge" (2004) 35 VUWLR 73.

19 Native Land Act 1909, ss 84-88.

20 Attorney-General v De Keyser's Royal Hotel Ltd [1920] AC 508 (HL). 
Once the Canadian and New Zealand colonial legislatures obtained full jurisdiction in native affairs and their Ministers the associated responsibility, they set about erecting statutory regimes for the management of the remaining tribal land. These regimes became Canada's Indian Act 1876 (the statutory framework for the land reserved by treaty) and New Zealand's native land legislation establishing the Native Land Court to oversee the conversion of customary title to Māori freehold land and provide for its management. ${ }^{21}$ In Canada the prerogative remained and was the basis for the Numbered Treaties by which the western prairies became opened up for white settlement. The retained land reserved to First Nations by these Treaties then became subject to the statutory regime of the Indian Act. By the end of the 20th century these regimes remained substantially in place, badly dated and marked by aboriginal ambivalence towards these relics of colonialist assimilation policies. These statutory regimes had operated to shield indigenous nations from complete landlessness whilst also facilitating some retention of cultural identity (though disfigured by the Anglo-legalism encasing it). What is notable about these regimes is the way in which the colonial legislatures retained the principle of executive oversight of the remnant tribal lands. The Indian Act gave the Minister numerous forms of open-ended discretion that statutorily replayed the predicate of ample, unreviewable authority that had underpinned the prerogative during the era of imperial management. Likewise, though in a slightly different way, the Native Land Court assumed a "quasiparental jurisdiction" over Māori freehold land. Though a court of record, its remit in monitoring the management of Māori land (and processes for its alienation) extended far beyond the purview of what is normally regarded as the judicial sphere.

Meanwhile during the imperial era, the disposition of Crown prerogative and authority to protect interests (land especially) of a tribal character as well as to mitigate the impact of settlement was the task of the governor. As noted, this important aspect of executive authority was never packaged and vested as a distinct empowerment in the constituent instruments for the settlement colonies. Then as now, the Crown adopted internal techniques for the disciplining and regularisation of its exercise of this multifaceted executive authority. This internal management of its discretionary powers occurred informally, through correspondence, the commissioning of colonial officers (either generally as protectors or superintendents, or for specific purposes) and the reporting back to superiors, and the adoption of regularised administrative procedures (treaty-making in Canada and land cessions in New Zealand) that were an expression of royal authority, not a limitation of it. In the granting of Crown land to settlers, however, governors' prerogative powers were limited formally even before the transmission of legislative authority to the colonial assembly, as with the Bathurst $(1826)^{22}$ and the Ripon Regulations (1831). ${ }^{23}$ Thus one sphere of the prerogative in the colonies was sliced off

21 Native Lands Act 1862; and Native Lands Act 1865.

22 The "Bathurst Regulations" (1826) on land disposal: Copies of the regulations lately adopted in the Canadas for granting waste lands in these provinces (House of Commons, April 1827) at 3-4.

23 See Peter Burroughs "Wakefield and the Ripon land regulations of 1831" (1965) 11(44) Historical Studies: Australia and New Zealand 452. 
and became highly regulated - the practices and procedures for granting Crown land to white settlers. The aspect of the prerogative that preceded those processes, the one by which the Crown made arrangements with the tribal occupants to vacate their land for settlement, or otherwise determined which of its ungranted land was so available, was never subjected to similar regulation. In Canada during the 19th century, the Royal Proclamation (1763) was not viewed as a limitation of Crown discretion so much as an expression of it. It contemplated the Crown as arbiter of its own proceduralism. It did not tie the governor and his officers to an inflexible legally compelled procedure, so much as issue (that is, proclaim) an indication to settlers of how they could expect the Crown to handle its prerogative (by not recognising direct purchases from tribes and by demarcating a line of settlement). The fact that the Crown generally kept to the treaty-making procedure it had announced in 1763 for dealing with the "ancient hunting grounds" of First Nations did not mean it regarded itself as obliged to do so in a manner compellable by law. One should not confuse a sovereign's efforts to maintain overall consistency and regularity in the exercise of its discretionary powers with an external legal obligation to do so. In 1838, Lord Glenelg advised the Earl of Durham, Governor General of Canada: ${ }^{24}$

However rigidly the Rules respecting the Disposal of Lands may be observed in general, and it is necessary to observe them with the utmost Strictness, yet if in any Case it be for the clear Advantage of the Indians to depart from those Rules the Departure ought without Hesitation to be sanctioned.

Through the 18th and 19th centuries and in the management of colonial affairs, we remain in a period where the imperial prerogative was disciplined internally by procedures and mechanisms that the Crown set for itself. Recourse to the Imperial Parliament was still occasional and usually to obtain enlargement of the Crown's executive capacity rather than to effect a diminution of it. ${ }^{25}$ Such disciplining and the establishment and consolidation of a special department to ensure this - the Colonial Office with its own permanent Under-Secretary ${ }^{26}-$ demonstrated the seriousness with

24 Despatch from Lord Glenelg to the Earl of Durham (22 August 1838) in Copies or Extracts of Correspondence Since 1st April 1835, between the Secretary of State for the Colonies and the Governors of the British North American Provinces, Respecting the Indians in those Provinces (House of Commons, June 1839) 5 at 9 .

25 Lord Mansfield's judgment in Campbell v Hall (1774) 1 Cowp 204, 98 ER 1045 was taken as limiting the Crown prerogative to erect non-representative legislative organs in colonies that had received English law or been promised a representative assembly. This format was regarded as premature in many colonies such as New Zealand (1840) and the mainland colony of British Columbia (1858), though, unusually, the colony of Vancouver Island was founded by prerogative (1849) and South Australia by statute (the South Australia Colonisation Act 1834 ( 4 \& 5 Will IV c 95)). This constraint of the prerogative necessitated permissive legislation from the Imperial Parliament enlarging the Crown's constituent power as to establish what was known as the "Crown colony".

26 The Colonial Office was a department of the War Office (as renamed the War and Colonial Office in 1801) with its own accommodation and permanent Under-Secretary (from 1825). It became a separate government department in 1854. 
which empire and the exercise of sovereign authority beyond the realm was being taken. As permanent Under-Secretary, James Stephen brought internal systems of recording and filing of correspondence in London in the poorly resourced offices in Downing Street. ${ }^{27} \mathrm{He}$ also oversaw issuance of the Rules and Regulations for Her Majesty's Colonial Service (1837). The Manual was not founded on the direct authority of the Queen (regulation of the civil service as a prerogative power) but that of the Secretary of State, and then did not even bear his signature. This Manual supplemented the formal Commissions and Instructions and became an indispensable tool for senior colonial officers. The Manual covered everything from the method for citizens to petition London (only through the governor), military expenditure and outfitting, how legislation was to be reported (with appropriate marginalia), to the size of stationery required for despatches (government issue only). ${ }^{28}$ Patronage and preferment were also key tools available to governors. The preface in the Manual as circulated (and periodically updated thereafter) stated that Lord Glenelg had "instructed them [the governors and other public officers in the colonial possessions of the Crown] to receive it as a rule for the guidance of their conduct on the several matters to which it relates". The Manual was instanced in the London-based Colonial Magazine (1840) as showing that the "mode ... in which he is to exercise his office shows how little of independence there is in his actions". ${ }^{29} \mathrm{By}$ such processes the imperial governor became "a kind of pointsman on the railway of thought between two stations" who acted as "a half-way relay station that could charge up, or scale down, the impulses transmitted in either direction". 30

Whilst the Imperial Parliament rarely legislated in colonial matters during the Victorian period, and the Crown's Ministers carefully protected the prerogative, it maintained an oversight through appropriations, especially in the retrenchment and demilitarisation after the defeat of Napoleon in 1815. This form of parliamentary vigilance over Empire intensified during the Victorian period with financial cutback becoming an incessant theme of imperial practice. Parliamentary audit reinforced the need for the kind of bureaucratic measures and regularising of governors' conduct of office that was then occurring in the Colonial Office, especially during James Stephen's (1836-1848) and then Herman Merivale's incumbency (1848-1859) as permanent Under-Secretary. This form of

27 E Trevor Williams "The colonial office in the thirties" (1943) 2(7) Historical Studies: Australia and New Zealand 141.

28 These were published as Rules and Regulations for Her Majesty's Colonial Service (W Clowes and Sons, London, 1843).

29 Robert Montgomery Martin (ed) The Colonial Magazine and Commercial-maritime Journal (Fisher, Son \& Co, London, January-April, 1840) vol 1 at 345.

30 Peter Burroughs "Imperial Institutions and the Government of Empire" in Andrew Porter (ed) The Oxford History of the British Empire: Volume III: The Nineteenth Century (Oxford University Press, Oxford, 1999) at 176, citing John Benyon Proconsul and Paramountcy in South Africa: The High Commission, British Supremacy and the Sub-Continent 1806-1910 (University of Natal Press, Pietermaritzburg, 1980) at 335. 
accountability was underlined by the emergence of the practice of printing parliamentary papers containing relevant correspondence $-\mathrm{a}$ form of transparency, Victorian style.

This is not to say that this position of non-justiciable Crown protection went unopposed or unchallenged. As early as the late-1830s when the principle of non-justiciability was emerging, the Aborigines Protection Society argued for a statutory code of aboriginal peoples' rights on an American model. This kind of suggestion made establishment figures, anxious in an era of Reform, shudder and found no traction in the Colonial Office. ${ }^{31}$ In Upper Canada during the same period and well into the 1840s, Methodist missionaries petitioned for Crown grants of the Anishinabe land under their missionary tutelage. Such well-known missionary figures of this time (and of mixed blood), such as Peter Jones, sought to render the collective title to such land legally cognisable by way of an inalienable trust under seal to make it less vulnerable to what they saw as the vagaries of Crown protection. When such pressure was placed explicitly or implicitly on the principle of the non-justiciability of Crown protection during the era of imperial authority in native affairs, London's response was to stress its reliance upon the judgement of its man-on-the-spot. Ministers and the Colonial Office politely deflected (or ignored) suggested mechanisms of formal accountability, such as a statutory code or an external independent watchdog. Rectitude rather than regulation was what the Victorian officialdom regarded as necessary in governing tribal peoples. ${ }^{32}$

Indigenous peoples' pressure upon the "political trust" principle continued once London had passed over jurisdictional authority to the Canadian and New Zealand legislatures. National courts and legislatures saw protection as the province of the executive branch. Through the late-19th and 20th century the Nisga'a of British Columbia fought for legal recognition of their right to their homeland, constantly bumping against the principle of non-justiciability until victory (of sorts) in Calder (1973). ${ }^{33}$ Māori likewise challenged the principle of the non-cognisability of subsisting traditional property rights, more latterly in the 1950s and 1960s through unsuccessful claims to a customary title over Ninety Mile Beach, ${ }^{34}$ the bed of the Wanganui River ${ }^{35}$ and the lakebeds of the

31 James Heartfield The Aborigines Protection Society: Humanitarian intervention in Australia, New Zealand, Fiji, Canada, South Africa, and the Congo, 1836-1909 (Hurst and Co, London, 2011) at 34. Standish Motte Outline of a system of legislation, for securing protection to the Aboriginal inhabitants of all the countries colonized by Great Britain, extending to them political and social rights, ameliorating their condition, and promoting their civilization / drawn up at the request of the Committee of "The Aborigines Protection Society" (John Murray, London, 1840).

32 Herman Merivale Lectures on Colonization (1842) II at 157.

33 For an account see Hamar Foster "We Are Not O'Meara's Children: Law, Lawyers, and the First Campaign for Aboriginal Title in British Columbia, 1908-28" in Hamar Foster, Heather Raven and Jeremy Webber (eds) Let right be done: Aboriginal title, the Calder Case, and the Future of Aboriginal Rights (University of British Columbia Press, Vancouver, 2007) 61.

34 Re the Ninety-Mile Beach [1963] NZLR 461 (CA).

35 Re the Bed of the Wanganui River [1962] NZLR 600 (CA). 
volcanic plateau in the central North Island. The claims to the lakebeds resulted in a political outcome ${ }^{36}$ and whilst the political route continued to be pursued for important territorial insignia of mana - mountains, lakes, beaches, rivers, islands and fisheries - New Zealand courts kept themselves carefully out of the frame. Whilst the pattern of political relations established in the 19th century diminished in intensity and with the decline in Māori political power during the 20th century, it nonetheless remained along with the unavailing attitude of the courts to this "political trust". Māori resumed their invocation of a subsisting customary title 40 years later and so powerfully with the claim to the Marlborough Sounds seabed, an action disarming in its ostensible simplicity as well as historical resonance and which generated the legalism to which I turn later in this article.

These are examples of how indigenous peoples knocked on official doors and pushed at the court door in order to obtain rights of more legal potency than reliance upon forms of Crown protections that called for a beneficent disposition of prerogative or which were wrapped insubstantially and scrappily into statute. Indigenous peoples' bitter experience had shown this combination of executive stewardship and its concomitant of judicial disengagement often to be inattentive, inconsistent and sometimes barely forthcoming. The failings of this protection have become the basis upon which historical or, as they are known in Canada, specific claims against the Crown have been admitted and processes put in place for their resolution.

\section{HISTORICAL CLAIMS}

In New Zealand and Canada this admission of historical/specific claims was initially a political gesture founded in the prerogative, although New Zealand introduced a statutory process of Waitangi Tribunal hearings to channel such claims. Australia has not admitted such claims to any forum of redress. It has limited the national mechanisms for cognisance of claims to those of a contemporary nature only and exclusively through the statutory framework of the Native Title Act 1993 (Cth). As I will also explain, governmental authority in the negotiation and resolution of contemporary claims in New Zealand and Canada likewise has associations with the prerogative. From an aboriginal perspective, contemporary claims are usually based upon the threat of governmental action to unextinguished rights or a claim to their fuller status by way of legal instantiation.

36 The Native Land Amendment and Native Land Claims Adjustment Act 1922, s 27, was a response to governmental unease over the possibility of the beds of navigable lakes being treated as Māori customary land and a freehold order issuing from the Native Land Court. It vested the beds of 14 lakes in the Crown, "freed and discharged from the Native customary title, if any" and set up the Arawa District Māori Trust Board which received income from the Crown and from fishing licences as agreed in the negotiations. This settlement was adjusted by Treaty settlement in 2004. Similar controversy surrounded ownership of Lake Waikaremoana and this dragged on until the Lake Waikaremoana Act 1971. 
In Canada, the specific claims resolutions process relates to allegations of specific (mostly historical) breaches by the Crown of a treaty, band management obligations under the Indian Act or other aboriginal rights. ${ }^{37}$ The resolution process was set out in another document of the same era, Outstanding Business - A Native Claims Policy (1982). Outcomes from this specific claims process and policy were moving so slowly that the conservative Harper Government, in consultation with First Nations, revised the policy under the title, Specific Claims: Justice at Last. ${ }^{38}$ The Specific Claims Tribunal Act $2008^{39}$ was designed to transfer slow-moving claims - defined in the Act as a claim for compensation that has not been resolved by the Minister of Aboriginal Affairs within three years of being filed - into a specialised Tribunal. Since 2007, the Dominion has cleared up a backlog of 541 claims at the assessment stage, and settled 95 claims through agreements totalling CAD 1.8 billion. During this time, Canada settled 16 claims through negotiated agreements with First Nations, totalling approximately CAD 557 million. The 16 settlements ranged in value from CAD 50,000 to CAD 307 million, with an average value of CAD 35 million. A CAD 307 million settlement, concluded with four First Nations in Ontario, is the largest specific claim settlement to date. As of March 2013, there were 106 claims under assessment and 231 claims in negotiation. ${ }^{40}$

The Supreme Court of Canada has spurred the resolution of historical claims by its majority judgment in the Manitoba Métis Federation case (2013). ${ }^{41}$ The majority, led by Chief Justice

37 Specific Claims Tribunal Act SC 2008 c 22, s 14 defining a specific claim as "... a claim based on any of the following grounds, for compensation for its losses arising from those grounds:

(a) a failure to fulfill a legal obligation of the Crown to provide lands or other assets under a treaty or another agreement between the First Nation and the Crown;

(b) a breach of a legal obligation of the Crown under the Indian Act or any other legislation - pertaining to Indians or lands reserved for Indians - of Canada or of a colony of Great Britain of which at least some portion now forms part of Canada;

(c) a breach of a legal obligation arising from the Crown's provision or non-provision of reserve lands, including unilateral undertakings that give rise to a fiduciary obligation at law, or its administration of reserve lands, Indian moneys or other assets of the First Nation;

(d) an illegal lease or disposition by the Crown of reserve lands;

(e) a failure to provide adequate compensation for reserve lands taken or damaged by the Crown or any of its agencies under legal authority; or

(f) fraud by employees or agents of the Crown in connection with the acquisition, leasing or disposition of reserve lands."

38 Indian and Northern Affairs Canada Specific Claims: Justice at Last (2007).

39 Specific Claims Tribunal Act SC 2008 c 22.

40 Indian and Northern Affairs Canada Progress Report-Specific Claims 2012-2013 (August 2013).

41 Manitoba Métis Federation v Canada (Attorney General) 2013 SCC 14, [2013] 1 SCR 623. 
McLachlin, held that the Crown had not honoured a promise contained in s 31 of the Manitoba Act 1870 to allocate land to Métis children. The Court ruled that government officials had been obliged to perform their offices under this Act fairly and in good faith as opposed to merely conducting themselves according to law. This historical failing to honour a promise recognised by statute was rendered justiciable by reason of s 35 of the Constitution Act 1982. How this judicial nudge will resolve into a court-based jurisprudence for the pursuit of wider historical claims (extending beyond the scope of a statutory promise as to include other forms of Crown undertaking) remains to be seen.

Perversely, there is a further potential and highly slippery foundation for the court pursuit of historical claims through the definition of aboriginal title the Supreme Court has been giving since the mid-1990s. As I explain below, common law aboriginal title originated as a legal means for the protection of customary rights in the present use and enjoyment that did not stumble on the principle of non-justiciability. The Supreme Court of Canada has recently (2014) confirmed its test for aboriginal title as given in Delgamuиkw (1997): $:^{42}$

\footnotetext{
As we have seen, the Delgamuukw test for Aboriginal title to land is based on "occupation" prior to assertion of European sovereignty. To ground Aboriginal title this occupation must possess three characteristics. It must be sufficient; it must be continuous (where present occupation is relied on); and it must be exclusive.
}

The bracketed words in the above passage are crucial. All the common law aboriginal title cases to date have relied upon present occupation as the basis of proof, but the definition leaves open the possibility of a past-day aboriginal title that crystallised at Crown sovereignty remaining legally unextinguished. At least one major Canadian academic has argued this, overlooking the impact upon innocent third party landholders. ${ }^{43}$ The Supreme Court has not given any continuity test for the exercise of common law title but for the continuity of the claimant group that is asserting it. To that extent the judicial definition of aboriginal title harbours the possibility, however faint, of an unextinguished past-day title subsisting over land whereover there is no current form of aboriginal use and enjoyment. This seeming incubation, which if realised would transform a possessory cause of action into a restitutionary one, needs squaring with the Supreme Court's refusal of leave (twice) in the Chippewas of Sarnia case. ${ }^{44}$ The Sarnia case involved the possessory claim to unextinguished

42 Tsilhqot'in Nation v British Columbia 2014 SCC 44, [2014] 2 SCR 257 at [25] (emphasis added). See Delgamuukwv British Columbia [1997] 3 SCR 1010.

43 Kent McNeil "Aboriginal Title on the Ground: Establishing and Protecting Occupation of Land" in Bruce Hodgins, Ute Lische and David McNab (eds) Blockades and resistance: Studies in action of peace and the Temagami blockades of 1988-89 (Wilfrid Laurier University Press, Waterloo, 2003) 147 at 153. The McNeil argument supposes that the issue of Crown grant - an executive act - does not in principle extinguish that which can only occur by valid cession (treaty or surrender, in Canadian parlance) or by clear legislation.

44 Chippewas of Sarnia Band v Canada (Attorney General) (2000) 195 DLR (4th) 135 (ONCA) confirming the judgment of Campbell J (Ontario SC 95-CU-92484, 30 April 1999). 
aboriginal title over third-party land on grounds of non-compliance during a series of 19th century transactions with the procedures of the royal proclamation rather than an action against the Crown for historical breach of duty. ${ }^{45}$ Though grounded upon an allegation of historical misconduct by the Crown, this was a possessory action that failed and which the Supreme Court refused to entertain.

The Sarnia case signals (one surmises) that the Supreme Court will not let innocent third-party owners of land be directly affected today by past Crown dealings, but the Manitoba Métis Federation case and orientation of the Delgamuukw test indicate that the Court might be prepared to develop principles that prod the Crown towards settlement of at least some types of specific/historical claims. In her dissent in the Van der Peet judgment (1996), Justice Beverly McLachlin presaged the awakened role that s 35 would take in the new century under her stewardship of the Court. She saw it as establishing constitutional aboriginal rights that could be of the common law but which also transcended it to provide rights that would set a firm foundation for settlement of claims, were liberal and generous toward the aboriginal interests, and considered the claim in the context of the historic way of life of the people asserting it. ${ }^{46}$ Presently there are many such historical claims proceeding through Canadian courts, most still at trial level. First Nations plaintiffs have drawn sustenance from the Supreme Court's vague notion of the "honour of the Crown" in Manitoba Métis Federation as a juridical lens to the past and the suggestion of justiciability of historical claims that this had brought but which the case law has still yet to explore.

Māori claims in New Zealand are based upon the Treaty of Waitangi; the instrument by which the Crown obtained sovereignty over New Zealand (1840) in return for a guarantee of the tino rangatiratanga of the chiefs amongst their own people as well as the property and other taonga (valued things) of Māori. As amended in 1985, s 6(d) of the Treaty of Waitangi Act $1975^{47}$ allows the Waitangi Tribunal to hear claims against the Crown for "any act done or omitted at any time on or after 6 February 1840, or proposed to be done or omitted, by or on behalf of the Crown". The Tribunal can conduct hearings into historical, as well as contemporary, claims for any:

... ordinance or Act, or the regulations, order, proclamation, notice, or other statutory instrument, or the policy or practice, or the act or omission, was or is inconsistent with the principles of the Treaty.

The Tribunal's reports have the status of "recommendations" and whilst the Tribunal has developed a formative jurisprudence on "remedies", the expectation under the Act is that any report is nonbinding and will form the basis for ensuing direct negotiation. This has meant that some claimants

45 Supreme Court Docket 28365. The Chippewas filed for a reconsideration of the application for leave and this was also declined (2002). The file record is online at Supreme Court of Canada "Docket 28365 The Chippewas of Sarnia Band v. Attorney General of Canada, et al. (Ontario) (Civil) (By Leave)" (3 December 2012) <www.scc-csc.gc.ca>.

$46 R v$ Van der Peet [1996] 2 SCR 507 at [232] per McLachlin J (dissenting).

47 Section 6(1): replaced, on 6 January 1986, by s 3(1) of the Treaty of Waitangi Amendment Act 1985. 
have bypassed the Tribunal process altogether, commencing with the Tainui-Waikato raupatu (confiscation) claim in 1995. Other claimants, commencing with the Ngai Tahu claim which, after the Tribunal hearing and voluminous Report (1986-1991) followed by a hiatus (1994-1996), was settled in 1997 (deed of settlement) and 1998 (confirmatory legislation). Direct negotiation proceeds according to the non-statutory procedures set out in the so-called "Red Book", which has gone through two editions (1999 and 2002). ${ }^{48}$

Historical claims have dominated Crown-iwi relations for the past 20 years, with the very important exception of Māori contemporary claims connected to the coastline. Historical claims have been at the core of Māori grievance in that they address past and colourable losses of land (especially) in breach of the Treaty of Waitangi that Māori regard as instrumental in their political marginalisation and economic deprivation. The resolution of Treaty claims has been a priority of recent governments. There has been no signal from New Zealand courts of jurisprudence analogous to the suggestiveness of the Manitoba Métis Federation case impelling the Crown to settle historical claims.

In the famous Mãori Council line of cases during the late-1980s and early-1990s, the Court of Appeal pressed for negotiated outcomes between Crown and Māori in the settlement of historical Treaty claims. This imperative had a clear statutory foundation in a direction from Parliament rather than a murky common law one generated by the courts themselves, although it maintained the historical pattern of characterising relations with Māori as primarily a matter for the executive branch. ${ }^{49}$ Section 9 of the State-Owned Enterprises Act 1986 subjected the Crown's statutory power to transfer state assets to the "principles of the Treaty of Waitangi" and was interpreted as requiring the Crown to reach an accommodation with Māori so as not to compromise the availability of these assets for the settlement of Treaty claims. Since then, the New Zealand courts have taken the broad position that the Treaty settlement processes are non-justiciable. ${ }^{50}$ Though New Zealand courts have been respectful of the unpleasant aftertaste associated with the Wi Parata case as not to cite it directly, their position is essentially its continuance. ${ }^{51}$ In addition, the Supreme Court has recently made it clear in Paki (2014) that New Zealand courts would not be entertaining any pursuit of

48 Office of Treaty Settlements Healing the Past, Building a Future: A Guide to Treaty of Waitangi Claims and Direct Negotiations with the Crown (1999 and 2002).

49 New Zealand Maori Council v Attorney-General [1987] 1 NZLR 641 (CA); Tainui Maori Trust Board v Attorney-General [1989] 2 NZLR 513 (CA); and Te Runanga o Muriwhenua Inc v Attorney-General [1990] 2 NZLR 641 (CA).

50 Jessica Andrew "Administrative Review of the Treaty of Waitangi Settlement Process" (2008) 39 VUWLR 225 .

51 David V Williams "Wi Parata is Dead, Long Live Wi Parata" in Claire Charters and Andrew Erueti (eds) Maori Property Rights and the Foreshore and Seabed: The Last Frontier (Victoria University Press, Wellington, 2007) 31. See Wi Parata v Bishop of Wellington, above n 14. 
historical claims on grounds of an outstanding legal duty affecting Crown management. The Court would not allow colourable Crown dealings in the past, as in the imperfect obtaining of cession from native owners, to be reconstituted today into an outstanding and enforceable fiduciary or relational duty. Young J put it strongly in rejecting any "examination of 19th century transactions through a 21 st century lens, with a resulting risk of distortion". ${ }^{52}$ Any rendering of Māori historical claims to court adjudication requires an approach, anyway, that can rest upon a specific and enabling constitutional provision similar to Canada's s 35 and the likes of which New Zealand lacks.

In New Zealand, then, historical claims are addressed either through the statutory procedure and the supportive administrative processes of Tribunal hearing and recommendation by way of report or through direct negotiation. Though these are highly disciplined processes, the Crown's prerogative hand to enter into settlement and sponsor the requisite legislation cannot be forced adversarially.

In any event, the political sphere has shown such a business-like and forthcoming attitude towards the resolution of these claims that judicial intervention would seem impertinent. Legislation for the resolution of Treaty claims has become a regular feature of the political landscape and the tone of media coverage has long since lost any querulous or begrudging flavour.

\section{CONTEMPORARY POSSESSORY CLAIMS AND THE DISPOSITION OF CROWN PREROGATIVE}

In Canada, comprehensive claims are territorial in scope and typically incorporate a claim both to self-government and a possessory aboriginal title (exclusive ownership rights). Their scope and the machinery for any settlement and implementation necessarily involve federal and provincial governments. These claims are associated with the federal government's policy and practice statement In All Fairness: A Native Claims Policy (1981). ${ }^{53}$ It was adjusted in 1986 after the Coolican Report (offering alternatives to blanket extinguishment) and initially applied in all provinces until some adjustments for British Columbia in the 1990s. ${ }^{54}$ There have been 26 comprehensive land claims settlements since 1973 and two stand-alone self-government agreements that have been concluded and are being implemented. Of the 26 concluded claims, 18 included provisions related to self-government. In March 2014 there were 100 active self-government and comprehensive land claim negotiation tables across Canada. ${ }^{55}$

52 Pakiv Attorney-General, above n 17, at [309].

53 Patricia Sawchuk (ed) In All Fairness: A Native Claims Policy: Comprehensive Claims (1981).

54 See Mary C Hurley Settling Comprehensive Claims (Parliamentary Information and Research Service, 2009).

55 Aboriginal Affairs and Northern Development Canada "Comprehensive Claims" (8 February 2015) <www.aadnc-aandc.gc.ca> 
First Nations self-government requires legislative authorisation in order to escape the straitening and deadening governance mechanisms of the Indian Act (for those subject to it) and/or to create new regimes tailored to particular indigenous communities. The Supreme Court has declined to recognise self-government as an inherent right under s 35, which means First Nations' organic polities lack meaningful legal stature without a legislative foundation and certainly in terms of any asset-holding and management viability. The Court has thus declined a Canadian jurisprudence of First Nations self-government analogous to federal Indian law in the United States, which starts from a presumption of residual and inherent tribal sovereignty. In other words, the Court will not put itself in the position of constructing self-government through an adversarial process. This construction of a framework of possessory proprietary rights became necessary with aboriginal title during the 1990s. Plainly the Court did not want to expose itself to a vastly larger and more awkward task of giving substance to any inherent right of self-government, an exercise far beyond its institutional competence (not to mention absence of democratic mandate). The forum for the addressing of First Nations' mechanisms of self-government remains the political one, fraught and problematic as this has been and remains. There is no question of any judicial nudging of the political branches on this key aspect of comprehensive claims by putting self-government into the compass of s 35. Instead, in 1995 the federal government announced its recognition of the inherent right to self-government under s 35 . This was, in effect, an announcement by the federal Crown of the basis upon which it would be managing its prerogative authority in the conduct of comprehensive claims, whilst at the same time realising that its positioning on self-government was a form of self-disciplining that its courts would not be enforcing against it.

It might be noted parenthetically here that in New Zealand, tino rangatiratanga has tended to be pitched in more situational terms than in the Canadian sense of what is usually a territoriallyassociated form of self-government. Tino rangatiratanga has been framed in language that largely eschews sovereignty talk, preferring the less combustible and pliant (as well as politically very serviceable) notion of Treaty partnership. The emphasis upon the Treaty and iwi as the rights and claims bearing polities of Māoridom, with whom claims are to be resolved, has revalidated and revitalised this traditional tribal structure, though not without controversy (particularly during the 1990s). In this way the ethnic self-identifying practices of Māori that demographics and urbanisation might possibly (though, of course, conjecturally) have taken elsewhere have been channelled back into this retribalisation. Māori political effectiveness with the dynamics of the MMP electoral system introduced in 1996, as well as the increasing embourgeoisement that Treaty settlements have oiled, explains why, or rather how, tino rangatiratanga has become less a demand on the national political system than a key part of its practice. This has been nowhere better demonstrated than in the foreshore and seabed controversy from which Māori emerged with their political potency enhanced. They are at the heart of the country's political life with a seriousness of presence of which indigenous peoples in Australia and Canada at present can only dream. Wondrously they have devised a shape-shifting political plasticity where they are simultaneously of 
the Crown sitting at the Cabinet table participating in executive branch decision making whilst also maintaining a distinct, separate relationship with that Crown. ${ }^{56}$

Whilst any effective operationalisation of First Nations self-government requires facilitative legislation, the legal recognition of extant tribal property rights can be achieved through court and without placing reliance entirely upon agreement with the Crown. Canadian law has recognised the possibility of a subsisting common law aboriginal title since Calder (1973), however it took 40 years before the Supreme Court actually gave tangible expression to such a title in the recent and important case Tsilhqot'in Nation v British Columbia (2014). The approach taken by the Court towards the nature and extent of judicially-determined title will enhance the breadth of the substantive outcomes on the table for negotiation and hopefully bring momentum to Canadian processes presently moving at a snail's pace compared to the antipodean. Also and as I explain later, Tsilhqot'in Nation has a direct bearing in New Zealand upon the nature of a Māori CMT under Te Takutai Moana Act 2011. In Canada, there is now the realised spectre of court determination of title as an alternative to negotiation. Hopefully and doubtless as the Supreme Court intended, this will have a stirring effect upon the pace of comprehensive claims settlement. The Canadian courts have consistently expressed the view that a negotiated outcome is preferable to a litigated one.

It is important to recall the genesis of common law aboriginal title and its removal of the longstanding non-justiciability bar to court enforcement of aboriginal title. The first recognition of common law aboriginal title by Canadian courts in the famous Calder case (1973) as indeed the equally famous Mabo No 2 case in Australia, occurred against a background of the failure of the political branches to legislate a land claims resolution regime in the face of rising aboriginal protest. The courts' willingness to recognise the common law foundation of aboriginal title came at a time when the political branches had shown persistent inability to move towards accommodation of contemporary land claims. Indeed, and in the face of strong aboriginal resistance, Prime Minister Trudeau's Government had issued a White Paper (1969) setting itself on a course for the dismantling of any remnant statutory rights and protection of treaty entitlements (mostly associated with the Indian Act) ${ }^{57}$ The recognition of common law rights, or rather judicial announcement of the clear possibility of such rights, thus conditioned the Crown's prerogative position and locked it into a format of rights-accommodation. It was an instance of a court using the common law in order to shape the character of the prerogative so as not to leave it a matter of untrammelled executive authority.

The development of a comprehensive claims policy was a response by which the dominion government activated and organised its authority under the prerogative to negotiate and enter into

56 Janet McLean "'Crown Him With Many Crowns': The Crown and the Treaty of Waitangi" (2008) 6 NZJPIL 35.

57 See SM Weaver Making Canadian Indian Policy: The Hidden Agenda 1968-70 (University of Toronto Press, Toronto, 1981). 
what essentially would be modern forms of treaty. It did this against the backdrop of there being a (newly appearing and inchoate) set of rights that the courts were prepared to recognise. The establishment of this machinery also necessitated forms of co-operative federalism drawing in those provinces where such claims arose (British Columbia and Quebec most notably). The practices that were put in place were extra-statutory, and a paradigmatic instance of the Crown internally disciplining its exercise of executive (prerogative) authority. The erection of such administrative procedures also required the federal government to have a threshold for the acceptance of claims, the nature of which has been difficult given the lack of clarity from the courts on the nature of aboriginal title. Whilst the Supreme Court has stressed the preferability of negotiated settlement, it has not given the federal government an altogether clear indication of how to set this threshold. Was the title and its requirement of "effective control" to be built to the "postage stamp", "lattice" or "territorial" model? That is, was the compass of an exclusive aboriginal title to be that of the land actually used and occupied all year by the claimants, was it a web or lattice of exclusive title patches joined by lines of non-exclusive rights, or was it territorial form with a much less demanding and factually constituted approach to customary use and occupation that took account of customary forms of authority? Whilst the Supreme Court seems to have opted for a more territorial approach in its recent Tsilhqot'in Nation judgment, the previous lack of clarity was hardly giving the federal government a firm idea of how to discipline the comprehensive claims process with the setting of clear admissions criteria. Of course, this is not the Court's fault because common law development is shaped by the facts in litigation and the pleadings, as well as (more fundamentally) parties' willingness to go to court in the first place. This is a reason why Australia and New Zealand have opted for statute to deal with contemporary aboriginal claims.

In the late-20th century public law setting, the Canadian federal government would have disciplined itself into the comprehensive claims processes knowing also that having set upon this course it would be amenable to judicial review, particularly on procedural grounds. The comprehensive claims processes were structured and have been managed so as to avoid this exposure. Also, with the adjustments of 1986 and 1995, they have been modified to take account of the further texturing suggested by s 35 .

The Tsilhqot'in Nation judgment has come at a time when First Nations have been expressing mounting dissatisfaction with the inaction of the comprehensive claims processes. Putting Calder and Tsilhqot'in Nation alongside and in the broader political contexts of their time, they acquire an uncanny parallelism. It could be said that common law aboriginal title has been a judicial initiative aiming implicitly to incentivise government negotiation of contemporary claims rather than to become an alternative to it. It has been designed to nudge the executive branch into agreement rather than to bypass it. It does this by equipping First Nations with the spectre of rights that encourage the Crown to deploy and discipline its prerogative more efficaciously (and which aboriginal rights anyway are constitutionally protected from extinguishment under s 35). These processes might have been kick-started by Calder and governmental anxiety about the courts 
assuming a more intrusive role, but they have acquired a momentum of themselves through which the government has disciplined its authority with running adjustment and occasional external oiling from the courts.

As I will explain, this relation between, on the one hand, the recognition of rights accomplished by executive process and, on the other, that which might be obtained through the courts, is one of which the New Zealand legislation on the foreshore and seabed is very aware. As in Canada, Australia and New Zealand both put in place elaborate administrative machinery simultaneously to organise the exercise of Crown authority and accommodate the extant common law rights that their courts had announced in principle to exist. Unlike Canada, where the machinery of the comprehensive claims processes leading to legal instantiation has been extra-statutory, Australia and New Zealand put in place statutory processes, respectively the Native Title Act 1993 (Cth) and the two foreshore and seabed statutes (2004 and 2011). ${ }^{58}$

New Zealand does not face contemporary land claims of the Canadian and Australian kind that encompass claims over vast areas of resource-rich land. Nonetheless, New Zealand has in recent years experienced its own present-day form of a contemporary aboriginal claim to unextinguished customary rights that in terms of the impact upon development of national resources has been of no less magnitude. This claim, or rather series of claims, has primarily concerned Māori rights around the coastline, although there have been similar consequences for claims to forms of customary rights over landmarks that have been held by the Crown. These claims to the foreshore and seabed have been (twice) put into statutory housing that situates Crown prerogative and executive authority beside the spectre of possible customary rights over marine areas.

The most recent example of a contemporary type has been the Māori claim relating to the generation of hydroelectricity and governmental privatisation of Mighty River Power. This was based both upon the historical basis of alleged Crown breach and hence the continuance of fiduciary or relational duty to Māori rather than being a claim simpliciter to contemporary unextinguished rights. In Paki (2014), the Supreme Court stressed that the claim to possessory customary rights had to proceed from the preliminary finding of fact that those rights had a foundation and continuance in the custom of the claimant group. ${ }^{59}$ Such claims required a present-day foundation in custom (a question of fact that was a necessary but not sufficient requirement for present-day legal stature) before their current legal status could be addressed. In the ascertainment of this factual status there were processes for determination, such as reference by the High Court to the Māori Appellate Court under s 61 of Te Ture Whenua Maori Act 1993. The key legal issues to be addressed once that factual threshold was crossed included their legal extinguishment or, as a juridical option less than

58 Foreshore and Seabed Act 2004; and Te Takutai Moana Act 2011.

59 Paki v Attorney-General, above n 17. The Court stressed the local nature of custom according to the claimant group rather than by reference to broad Māori custom at large, for instance at [17], [86], [110] and [135]. 
legal obliteration, possible continuance by way of imposition upon the Crown of a fiduciary duty. The Court was clear that no such duty would arise from past Crown dealings, though it did not rule out the possibility of there being a Crown duty of a fiduciary or relational character attaching to extant customary rights (of which there were none in this case).

The clear inference of Paki is that any Crown accountability before its own courts with regard to its disposition and management of land held by it and subject to a Māori claim will be limited to possessory actions for present rights rather than an action on those that have been lost, however egregiously. This approach certainly squares with the intellectual genesis of common law aboriginal title as a means by which extant traditional land rights might be protected from further loss. Apart from the result in the Te Weehi case, ${ }^{60}$ this doctrine has been more suggestive in the New Zealand setting than it has been in terms of substantive outcomes. Nonetheless the prospect of court recognition and percentage quantification of the Māori common law interest undoubtedly pressed the Crown towards settlement of the fisheries claims during the early 1990s. The spectral presence of the common law doctrine incentivised the negotiated settlements (1989 and 1992). ${ }^{61}$

In the past 25 years agreements between Crown and Māori as to the disposition of state assets and the associated exercise of legislative authority have become commonplace. The sea fisheries settlements were a theme-setting instance. Numerous Treaty settlements have been legislated in the last 20 years such that they are a fact - though a very important one - of national political life. Te Takutai Moana Act 2011 anticipates the continuance of this phenomenon with regard to marine areas, and explicitly states (s 96(1)(b)) that Crown agreements for the recognition of Māori CMT (the fullest set of rights Māori might hold) can only come into effect by Act of Parliament. Crown agreements with Māori for the settlement of historical claims and this important category of contemporary claim therefore require confirmatory legislation. Whilst there may be a New Zealand constitutional convention that Parliament will endorse the agreement reached by the executive branch, statutory endorsement is the requirement for legal enforceability. In that sense, New Zealand's legal system would seem not to have moved far from its position a century ago.

What is different, of course, is the proliferation of agreement-making between the Crown and Māori, something of which there was not much for most of the 20th century. Also, and in a more general way, Māori have shown themselves the most adept practitioners of the issue-led agreementmaking and coalition-cooking that characterise the politics of MMP. Recently, New Zealand historians like Richard Boast and Vincent O'Malley have been stressing the importance of Crown-

60 Te Weehi v Regional Fisheries Officer [1986] 1 NZLR 682 (HC).

61 Maori Fisheries Act 1989; and Treaty of Waitangi (Fisheries Claim) Act 1992. See the Deed of Settlement at Her Majesty the Queen and Maori "Deed of Settlement" (September 1992) Te Ohu Kaimoana <www.teohu.maori.nz>. 
tribe agreements in shaping New Zealand politics during the second half of the 19th century. ${ }^{62}$ These were our form of Covenant Chain, a series of improvisational agreements based upon the reality of the authority of tribal polities and the necessity to accommodate. Those politics are back in a modern form. We can see the dynamism of the legal principles that have been their backdrop in the example with which I conclude, Te Takutai Moana Act 2011.

\section{CUSTOMARY MARINE TITLE AND TE TAKUTAI MOANA ACT 2011}

Though the New Zealand courts have been markedly chilly towards being drawn into historical claim-making, the Supreme Court's recent but cautious willingness to accept in principle the possibility of customary rights that remain in the present use and enjoyment is consistent with the position of the Court of Appeal in the Ngati Apa case (2003) and the intense legalism that this case generated. ${ }^{63}$ The Ngati Apa case and the ensuing statutes, the ill-fated Foreshore and Seabed Act 2004 and Te Takutai Moana Act 2011, supposed there might be, in fact and at law, existing, ascertainable Māori rights over marine areas. The Court of Appeal judgments foreshadowed these rights either by way of the statutory customary title under Te Ture Whenua Maori Act 1993 or as common law rights. Ngati Apa left open - because the jurisdictional question before the Court did not have to address - many questions about the nature, extent and possible extinguishment of those rights. Still, the Court's acceptance that in principle and point of law such rights might subsist around the country's coastline set off a political debate that eventually became predicated on the basis such rights actually were there, including those of an exclusive character (though qualified by a narrow band of public and specific statutory rights).

The foreshore and seabed statutes of 2004 and 2011 set in place mechanisms for the determination of those rights, but it was of the essence in the political imperative behind both that these, though highly indeterminate, were rights in possession and in present enjoyment under Māori custom. Both statutes also put the legal footing of those rights entirely inside the respective statute. Section 6 of Te Takutai Moana Act 2011 is as disingenuous a provision as any one is likely to encounter. Doubtless its goal is rhetorical, being to reassure Māori of the death of the 2004 statute whilst simultaneously accomplishing almost exactly the same totalising result. It provides that the

62 On which see Richard Boast "Recognising Multi-Textualism: Rethinking New Zealand's Legal History" (2006) 37 VUWLR 547; and Richard Boast "Treaties Nobody Counted On" (2011) 42 VUWLR 653. The Canadian case law on aboriginal title also implicitly anticipates the resumption of a historical pattern of Crown-First Nations relations through modern treaty-making (with a contemporary justiciable gloss). This resumption of relations through agreement-making has occurred not only in the sea fisheries settlement, the many Treaty claims settlements, and the design of Te Takutai Moana Act 2011 where the spectre of Māori legal entitlement has prodded Crown into organising its executive authority through detailed administrative processes, but also more generally in the entirely political sphere of the coalition brokering of MMP in which Māori are adept players.

63 Attorney-General v Ngati Apa, above n 2. 
2004 Act is not to be regarded as the statutory extinguishment of Māori rights around the coastline, but then it also provides that those rights "are restored and given legal expression in accordance [that is, not otherwise than by] this Act". The paradox is that while the 2011 Act eliminates any foundation for Māori rights around the coastline other than in the statute itself, the interpretation of its provisions will necessitate recourse to the overseas jurisprudence.

Further, by giving such detailed statutory shape to a potential form of Māori marine area right exclusivity or, as the 2011 Act has termed it, customary marine title (CMT) - the Act necessarily accepts what in Ngati Apa and Paki was taken as a possibility within the jurisdiction and in need of factual determination by the Māori Land Court. The 2011 Act thus replaces the jurisdiction of the Māori Land Court to ascertain customary title and to transmute it into freehold title (with all the problematic differentiation this would have entailed between different legal types of marine land) with a simpler and more honed form. The Act erects machinery so elaborate that any purposive interpretation must presume that the spectrum of rights it provides for are capable of instantiation through the statutory mechanisms of negotiated agreement or court determination. The statutory CMT is subject to public and conferred rights (ss 26-28) but then adds a rather extraordinary provision in $\mathrm{s} 11$ concerning the "special status" of the common marine area, providing that no one - not even the Crown - "owns, or is capable of owning, the common marine and coastal area". Thus the common marine and coastal area is a sphere of imperium only where any private and vested rights can have no more than the status of statutory licence. This is suspiciously like the public domain of the 2004 statute. In that one of the two forms of Māori rights under the Act, CMT envisages a form of exclusivity (qualified by public rights), the statute (like its vilified 2004 predecessor) brings an outcome that the New Zealand common law simpliciter would probably have never delivered (in my estimation), but of which we shall never know. ${ }^{64}$ In renouncing the property of anyone over the common marine area and constituting the possible rights of everyone, the statute gives a form of Clayton's ownership: it is the ownership you have when no one can have ownership.

Te Takutai Moana 2011 resonates with the themes that have underpinned the Crown's conduct of relations with its aboriginal peoples in a modern and distinctly Kiwi setting. The Act takes those themes into another and new chapter of historical development. It replaces an executive authority previously founded upon a prerogative that was becoming exposed in any future exercise to the unknown effect of a set of indeterminate common law rights. The statute provides for the instantiation of those rights either by agreement or court determination, though as a species of possessory entitlement deemed not to be proprietary. It sets benchmark statutory tests for both forms

64 This was not the position of other writers too many to list or cite fully here but I can mention Shaunnagh Dorsett, Jock Brookfield, Richard Boast, Claire Charters, Jacinta Ruru and David Williams. In various ways these colleagues argued against my position (which the Waitangi Tribunal endorsed as likely to be taken by a New Zealand court) and suggested that the true New Zealand common law position was similar to the dissenting position of Kirby J in Yarmirr v Northern Territory [2001] HCA 56, (2001) 208 CLR 1 (a qualified exclusivity over marine territory was possible under the common law). 
that ensure the Crown does not give away by agreement more than a court would by judicial determination. In that sense the statute straitens the Crown's executive hand more than would occur through negotiation and agreement under its ordinary executive capacity. It is a statutory inversion of the usual inducement to a negotiated settlement that would arise against a backdrop of (and the courtroom gamble on) indeterminate rights: in reaching a CMT agreement, the Crown cannot be more generous than a court, but, one supposes, it can be less. Since it would take a brave court to refuse confirmation of a CMT agreement on grounds of it not satisfying the statutory test, the Act's approach invites courts facing the task of confirmation to be setting a lower, less exacting threshold as not to scupper negotiated outcomes.

The test for a CMT is set out in s 58 of the Act. It incorporates key elements of the approach taken by Canadian and Australian courts, in that it constitutes the CMT from use and occupation at the time of Crown sovereignty (Canada) but requiring the claimants' holding of the claimed area in accordance with tikanga, the traditional laws and customs and connection test (Australia). These are separate elements in the Act suggesting that the two-fold test of "use and occupation" and tikanga (normative authority) must be satisfied independently. The Act does not specify the intensity of use and occupation required for the fuller set of entitlement represented by a CMT (as opposed to the lesser, protected customary right). In a recent Australian case, Finn J said that the extensive case law on "occupation" as it related to land were of "no particular assistance". The "difficulties", he said, "in 'occupying' in any conventional sense sea waters, and sandbanks and reefs below the high water mark are self-evident". ${ }^{65}$ Nor, for that matter does it amplify how a group holds an area in accordance with tikanga or how that tikanga must be oriented towards the area claimed. Tikanga is defined broadly in s 9 as "Māori customary values and practices." Unlike the Canadian approach, there is a clear continuity requirement and recognition that the right must be in the current exercise. The Act anticipates a reform the Australians have been considering to ease the probative burden and grinding slowness of native title processes. ${ }^{66}$ It establishes a presumption of continuity of use and occupation that must be rebutted by those opposing the application. As noted, the Act is a device to bypass the uncertainties of common law development and to replace an uncertain impact upon the Crown's negotiating hand with a more knowable statutory framework.

In that the test given for a CMT under s 58 of the Act leaves open questions surrounding the threshold of the use and occupation, and the orientation of tikanga, the statute hardly encourages CMT agreements. Nonetheless, the recent Supreme Court of Canada judgment in Tsilhqot'in Nation would suggest a more territorial than parcel-by-parcel and time-consuming, resource-depleting

65 Akiba v Queensland (No 3) [2010] FCA 643, (2010) 270 ALR 564 at [255].

66 The Australian Law Reform Commission is presently considering this matter, which has been in the offing for several years (including a suggestion by the present French CJ as far back as 2009). For discussion, see Lisa Strelein "Reforming the Requirements of Proof: The Australian Law Reform Commission's Native Title Inquiry" (2014) 10(8) ILB 6. 
"postage stamp" approach. This would also occur by looking at the two tests as a single one rather than as two separate probative steps (as the formatting of s 58 can be taken to require). That is, "use and occupation" and tikanga must relate to the other, and strong tikanga can cover areas where use and occupation is less intense than others. This would suggest that the nature of the tikanga must be local and directed towards the particular area being claimed (rather than being a general, almost platitudinous and sentimental invocation of Māori association with the sea at large). This meshes with the approach to Māori custom recently taken by the Supreme Court in Paki.

Recent Australian case law also suggests a territorial approach. The Australian courts have asked "what are laws and customs?" that give rise to a native title. The courts have distinguished rules of customary law and practice "having normative content" from mere "observable patterns of behaviour": 67

... the rules which together constitute the traditional laws acknowledged and traditional customs observed, and under which the rights or interests are said to be possessed, must be rules having normative content. Without that quality, there may be observable patterns of behaviour but not rights or interests in relation to land or waters.

The courts have adopted the thinking of HLA Hart in this regard, citing his definition in The Concept of Law: ${ }^{68}$

What is necessary is that there should be a critical reflective attitude to certain patterns of behaviour as a common standard, and that this should display itself in criticism (including self-criticism), demands for conformity, and in acknowledgements that such criticism and demands are justified, all of which find their characteristic expression in the normative terminology of "ought", "must", and "should", "right" and "wrong". 69

Finn J gave a "working definition" at trial in Akiba No 3 (2010). He said: "It is that 'customs' are accepted and expected norms of behaviour, the departure from which attracts social sanction (often disapproval especially by elders). ${ }^{170} \mathrm{He}$ noted that the sanction of disapproval for deviant behaviour by a member of the society recurred in the evidence before him. The Australian courts have been

67 Members of the Yorta Yorta Aboriginal Community v Victoria [2002] HCA 58, (2002) 214 CLR 422 at [42] per the plurality judgment.

68 Harrington-Smith $v$ Western Australia (No 9) (2007) 238 ALR 1 at [996] per Lindgren J; and Akiba v Queensland (No 3), above n 65, at [171] per Finn J.

69 HLA Hart The Concept of Law (Oxford University Press, Oxford, 1994) at 57.

70 Akiba v Queensland (No 3), above n 65, at [173]. 
clear that this proof is not affected by non-indigenous presence in the claimed area that was not in accordance with traditional laws and customs. They have stated that: ${ }^{71}$

... a society's normative system containing laws and customs relating to access to, and use of territory,

do not cease to embody such laws and customs because others who are strangers to that society are

unaware of, disregard, or simply do not accept those laws or the strictures they impose.

Thus, for the generation of CMT agreements for the Crown to present to Parliament, the Crown must erect an administrative machinery that observes good procedure and that delivers outcomes which have applied the s 58 test as not exceeding what a court would order. Te Takutai Moana Act recognises and frames comprehensively the Crown's executive capacity to make CMT agreements with Māori. The statute carries elements both of the old and the new legalism. The political trust continues to inhabit those relations in that (one presumes) the courts cannot force the Crown's prerogative with regard to the introduction of the legislation necessary to bring a CMT into legal effect. Yet the Act also acknowledges the new era of court recognition of possessory actions by aboriginal peoples against the Crown that began (in New Zealand) during the mid-1980s. It even takes that era further by establishing a form of entitlement over the common marine area that surpasses what the New Zealand courts might have done off their own bat and even at their boldest.

\section{CONCLUSION}

New Zealand and Canada share a common law heritage and a very similar pattern of relations with their indigenous tribal peoples during the 19th century when the conduct of those relations was conceived as a political trust requiring the Crown's protection of the collective tribal rights. Originally this duty was anchored in the prerogative. This was a duty calling for the beneficent deployment of various forms of prerogative that governments (imperial and colonial) saw as requiring flexibility and adaptivity. It was regarded as an inherently political trust under the remit of the executive branch and that the courts would not enforce, though its compass could be altered by statute so that its ambit was enlarged (the Indian Act in Canada) or its justiciability affected by legislation (the Native Land Acts in New Zealand). Today, the Canadian mechanisms for the resolution of First Nations' comprehensive and specific claims reflect the peculiarities of their constitutional system and history, in particular its federal system and the movement into rightsbased constitutional adjudication (1982). The Constitution Act 1982 included s 35 with its recognition of "existing aboriginal and treaty rights", a provision that has licensed the expansive line of the Supreme Court under Chief Justice McLachlin. Likewise the New Zealand mechanisms to address historical and contemporary claims reflect the country's constitutional journey. These include the effect upon the Crown's legislative programming of the continual deal-making with Māori, necessitated by the electoral system reform of the 1990s and the politics of coalition. In both

71 Neowarra $v$ Western Australia [2004] FCA 1092 at [310] per Sundberg J; and Akiba v Queensland (No 3), above $\mathrm{n} 65$, at [257]. 
jurisdictions, settlement of historical and contemporary claims ultimately engages the sovereign prerogative of the Crown in Parliament. The modern legalism can prod and nudge this authority by dressing it in concepts that give traction to those claims and press the Crown to establish a disciplining machinery for their consideration and eventual resolution. Ultimately, however, the settlement of historical and contemporary claims requires a political will to ask Parliament to give legal form to settlement. Even with the disappearance of the political trust foundation to Crown relations as a relic of imperial paternalism, and even with the constitutional foundation such as Canada's s 35, this is a point that the Crown's courts have yet to require. As the Canadian courts, more than the New Zealand ones, edge vaguely and haphazardly closer towards forcing the Crown's hand in the resolution of First Nations' claims, the outcome has been political paralysis and a stasis in the settlement of claims that compares unfavourably to New Zealand. 
